Pengembangan model latihan konsentrasi pada tembakan free throw pemain bola basket

\title{
The development of a concentration training model on free throw shots basketball players
}

\author{
Dedi Iskandar ${ }^{1}$, Gilang Ramadan ${ }^{2}$ \\ 1,2 Department of Physical Education, Health, and Recreation, \\ STKIP Muhammadiyah Kuningan, JI. R.A. Moertasiah Soepomo No. 28 B, Kuningan, \\ 45511, Indonesia
}

Received: 24 September 2018; Revised: 26 December 2018; Accepted: 20 April 2019

doi) https://doi.org/10.29407/js_unpgri.v5i1.12493

\begin{abstract}
Abstrak
Tujuan dari penelitian ini adalah untuk mengembangkan model latihan konsentrasi pada tembakan free throw pemain bola basket serta mengukur sejauh mana proses latihan konsentrasi pada tembakan free throw pemain bola basket. Proses penelitian ini diawali dengan analisis kebutuhan dengan metode pengamatan lapangan dan dilanjutkan dengan proses pengembangan latihan konsentrasi pada tembakan free throw pemain bola basket sesuai dengan karakteristik yang dibutuhkan. Pengembangan model latihan ini dilakukan dengan menjalankan 10 langkah menurut Brog and Gall dan menghasilkan suatu produk dari model latihan konsentrasi pada tembakan free throw pemain bola basket sesuai dengan kebutuhan dan kesesuaian dengan apa yang dibutuhkan. Berdasarkan hasil analisis pada uji coba kelompok kecil didapat rata-rata pilihan sebesar $82,10 \%$, sedangkan pada uji coba kelompok sedang nilai yang didapat rata-rata $87,56 \%$, Sedangkan pada uji coba kelompok besar rata-rata pilihan sebesar 90,49\%. Hal ini menyatakan bahwa model latihan konsentrasi pada tembakan free throw pemain bola basket sangat layak untuk digunakan.
\end{abstract}

Kata kunci: konsentrasi, free throw, model latihan, pengembangan.

\begin{abstract}
The purposes of this study were to develop a concentration training model on free throw shots basketball players and to measure the extent of the process of concentration training model on free throw shots basketball players. The process of this research began with a need analysis with field observation method and continued with the process of the development of a concentration training model on free throw shots basketball players according to the characteristics needed. The development of this training model was carried out by applying 10 steps according to Brog and Gall and producing a product from concentration training model on free throw shots basketball players according to the needs and the suitability needed. Based on the results of the analysis on the small group trials the average choice was $82.10 \%$, whereas in the medium group trials the average values obtained was $87.56 \%$, while in the large group trials the average choice was $90.49 \%$. This stated that the concentration training model on free throw shots basketball players was very feasible to use.
\end{abstract}

Keywords: concentration, free throw, training model, development.

Email : gilangramadan89.umku@gmail.com

No Handphone : +6281322007004
p-ISSN: 2548-7833

e-ISSN: 2477-3379 


\section{PENDAHULUAN}

Di era berkembang saat ini masyarakat mulai menyadari tentang pentingnya olahraga baik sebagai olaharaga rekreasi, olahraga prestasi maupun olahraga pendidikan. Dengan semakin pahamnya masyarakat tentang pendidikan tentu hal ini berimbas semakin banyaknya partisipasi masyarakat dalam melakukan aktivitas olahraga, salah satunya adalah bola basket yang perkembangannya semakin lama semakin pesat dimulai dari setiap sekolah-sekolah yang memiliki lapangan bola basket. Selain itu ditandai dengan semakin berkembangnya Liga Basket Indonesia (IBL). Hal ini membuat olahraga di Indonesia saat ini semakin di kenal di berbagai kalangan masyarakat baik itu anak-anak, remaja maupun orang dewasa.

Berbanding terbalik dengan popularitas bola basket dari tahun ke tahun mengalami peningkatan dari jumlah penggemar bola basket hal ini bisa di lihat dari banyaknya penonton yang menonton langsung ke stadion, membuka website terkait bola basket dan melakukan langsung aktivitas olahraga bola basket di lapangan. Dengan melihat hal itu tentunya perlu adanya peningkatan kualitas seiring dengan perkembangan bola basket yang buka sekedar permainan rekreasi tetapi untuk mencapai prestasi yang diinginkan. Ramadan \& Iskandar (2018) menyatakan bahwa prestasi olahraga pun berbanding lurus dengan fasilitas yang ada selama proses latihan dengan semakin baiknya fasilitas yang diberikan akan berbanding lurus dengan prestasi yang diraih. Latihan adalah aktivitas untuk meningkatkan kemampuan (kemahiran) berolahraga dengan menggunakan berbagai peralatan yang standar sesuai dengan tujuan dan kebutuhan cabang olahraganya. Dalam mengembangkan olahraga bola basket tentunya peningkatan SDM pelatih dan atlet perlu mendapatkan perhatian guna meningkatkan prestasi bola basket.

Perkembangan prestasi bola basket Indonesia justru tidak terlalu bagus di wilayah ASEAN apalagi se-ASIA, fakta ini mencerminkan bahwa olahraga ini belum dapat di maksimalkan secara optimal untuk berprestasi 
setidaknya di ASEAN, sehingga perlu mendapat perhatian bersama dari berbagai pihak baik akademisi, pelatih maupun pemain atau atlet. Peranan akademisi dinilai sangat central dan dapat memberikan peranan besar apabila akademisi mendapat mengembangkan teori kepelatihan dengan pelatihan dilapangan sehingga proses pelatihan yang dilakukan bukan hanya sekedar pengalaman pelatih dalam menjadi atlet saja tetapi berdasarkan riset sehingga dalam perkembangan bola basket di Indonesia dapat dimaksimalkan. Pencarian atlet berbakat di Indonesia pun amatlah sulit karena dalam hal ini proses pencarian bakat sorang atlet bola basket sangat tergantung pada kompetisi di level sekolah ataupun level universitas (Wang, Wang, \& Ma, 2013). Faktor tersebut mengakibatkan proses pencarian bakat amatlah terbatas sehingga dapat dikatakan banyak pencari bakat bola basket mencari bibit pemain dari kalangan mahasiswa yang tidak tahu riwayat pelatihannya selama di level junior begitu pun pelatih yang jumlahnya tidak terlalu banyak bahkan sebagian besar pelatih di level sekolah adalah seorang guru dengan spesialisasi cabang olahraga yang lain berusaha menjadi pelatih bola basket. Amatlah penting seorang akademisi bisa berkontribusi lebih selain dalam hal teori juga dalam hal pelatihan sehingga banyak dari para akademisi olahraga menjadi pelatih bola basket (Ramadan \& Iskandar, 2018). Dengan melihat peluang ini tentunya perlu adanya peningkatkan kualitas pelatih dalam merancang pelatihan sehingga dapat menghasilkan prestasi yang baik.

Dalam masa perkembangan saat ini tentunya masih banyak kekurangan yang harus dilengkapi guna meningkatkan prestasi, kekurangan pertama adalah pemahaman pelatih dalam menyusun program latihan. Sumber daya manusia perlu diperhatikan terutama seorang pelatih harus menjadi suatu perhatian dan kewajiban bersama sehingga setiap camp pelatihan bola basket harus dapat dilatih oleh pelatih yang berkompeten (Robert, 2010).

Permainan bola basket adalah permainan yang sangat mengandalkan kondisi fisik yang prima untuk dapat tampil maksimal di 
lapangan, konsentrasi yang tinggi (Raôui \& Thomas, 2012). Teknik free throw merupakan salah satu teknik yang harus dikuasai oleh setiap pemain bola basket agar dapat menciptakan angka, dalam melakukan teknik free throw tentunya tidak semudah yang di perkirakan, perlu teknik yang baik agar bola dapat masuk ke keranjang (Diane, 2009). Salah satu kendala yang sering dihadapi oleh atlet dalam melakakukan free throw adalah menurunnya kadar konsentrasi setiap pemain sehingga tidak fokus pada sasaran. Model latihan yang biasanya diterapkan oleh pelatih biasanya selalu menekankan pada aspek tekniknya saja sehingga pelatih lupa dengan keahlian khusus yang perlu dimiliki seorang atlet atau pelatihan yang dilakukan akan mengkibatkan kebosan sehingga sangat perlu seorang pelatih memerhatikan aspek-aspek lainnya dalam meningkatkan kemampuannya (Sarang, 2018).

Dalam proses pengembangan latihan konsentrasi tentunya harus melalui beberapa tahap agar dapat menghasilkan sebuah model yang berkualitas. Proses pengembangan yang dilakukan diawali dengan studi pendahuluan, dilakukan guna mengetahui seberapa besar kebutuhan yang diperlukan guna memecahkan sebuah masalah. Studi pendahuluan diawali dengan penyebaran angket kepada para atlet yang notabene merasakan apa yang sebenarnya terjadi dalam sebuah proses latihan sehingga peneliti memiliki dasar yang kuat dalam mengembangkan sebuah model guna memecahkan sebuah masalah.

Dengan membuat model latihan konsentrasi sesuai dengan apa yang diperlukan dalam aspek free throw tentu akan membuat pelatihan semakin bervariasi bukan saja untuk meningkatkan faktor fisik, teknik dan taktik saja tetapi faktor mental juga perlu mendapat perhatian dan pembenahan agar peningkatkan kemampuan pemain atlet dapat meningkat dan menghasilkan prestasi yang diinginkan (Alexander, 2016). Pada akhirnya dengan mengembangkan model latihan konsentrasi pada tembakan free throw diharapkan akan memperkaya pengetahuan pelatih dalam meningkatkan kemampuan atletnya. 
Berdasarkan penjelasan tersebut, penelitian ini memiliki urgensi yang sangat tinggi karena kurangnya penelitian yang serupa untuk mengembangkan model latihan konsentrasi, tetapi ada beberapa penelitian sebelumnya yang memiliki kemiripan seperti penelitian Rosmi (2017) dengan judlu,"Pengaruh Latihan Autogenic Relaxation Terhadap Konsentrasi dan Keberhasilan Free Throw Bola Basket", penelitian Kurniawan, Noris Alim \& Sudarso (2014) dengan judul,"Hubungan antara Tingkat Konsentrasi Ssiswa Dengan Ketepatan Free Throw dalam Permainan Bola Basket", penelitian Setiawan et al. (2015) dengan judul,"Internal Locus Of Control dan Self-Efficacy Pemain Bola Basket dalam Melakukan Free Throw'. Dari ketiga penelitian sebelumnya yang pernah dilakukan memang memiliki perbedaan karena memang penelitian ini belum pernah dilakukan. Sehingga penelitian yang dilakukan ini memiliki kebaharuan dalam cabang olahraga bola basket karena belum pernah dilakukan sama sekali.

\section{METODE}

Penelitian ini menggunakan pendekatan penelitian dan pengembangan. Sedangkan model pengembangan yang digunakan adalah model pengembangan Research \& Development ( $R$ \& D) dari Borg dan Gall, dalam R\&D yang dikemukanan oleh Borg, Walter R \& Gall (1983) terdapat sepuluh langkah yang harus dilalui untuk memperoleh hasil antara lain: (1) Dalam langkah awal yang harus dilakukan adalah pengumpulan informasi terkait masalah yang terjadi di lapangan, dalam hal ini pengumpulan informasi (kajian pustaka, pengamatan subyek, persiapan laporan pokok persoalan); (2) Ketika pengumpulan informasi dirasa telah cukup maka langkah selanjutnya melakukan perencanaan (pendefinisian keterampilan, perumusan tujuan, dan uji coba skala kecil); (3) Mengembangkan bentuk produk awal merupakan langkah awal dalam memutuskan model atau cara apa yang akan dikembangkan dan merencanakan (penyiapan model latihan, penyusunan buku pegangan, dan perlengkapan evaluasi); (4) Melakukan uji lapangan permulaan atau uji coba skala kecil (menggunakan 6-12 subyek); (5) Melakukan revisi 
terhadap produk pada skala kecil pada expert judgment (sesuai dengan saran-saran dari hasil uji lapangan skala kecil); (6) Melakukan uji lapangan skala sedang (dengan 30-100 subyek); (7) Melakukan revisi produk pada skala sedang pada expert judgment (berdasarkan saran-saran dan hasil uji coba skala sedang); (8) Uji lapangan skala besar dengan 40-200 subyek; (9) perbaikan produk akhir sebelum disebar luaskan; dan (10) Membuat laporan mengenai produk pada jurnal, bekerja dengan penerbit yang dapat melakukan distribusi secara komersial.

\section{Penelitian Pendahuluan}

Penelitian dan pengembangan model latihan konsentrasi pada tembakan free throw bola basket di awali dengan proses pemikiran yang ilmiah dengan melakukan analisis kebutuhan (need assesment). Proses analisis kebutuhan dilakukan dengan melakukan pengamatan lapangan, mengamati proses yang terjadi dilapangan dan mengamati proses latihan yang dilakukan agar semua permasalahan yang ada dapat dirumuskan dan dipecahkan dengan produk yang tepat pada sasaran, sehingga proses penelitian yang dilakukan dapat memecahkan permasalahan dan mengembangkan proses latihan kosentrasi pada tembakan free throw bola basket secara menyeluruh.

\section{Perencanaan Pengembangan Model}

Model latihan kosentrasi pada tembakan free throw bola basket dikembangkan dengan menggunakan langkah pengembangan (Borg, Walter R \& Gall, 1983). Dalam setiap tahap penelitian dan pengembangan yang dilakukan terdapat langkah-langkah rancangan yang penjelasannya diuraikan. Berikut ini adalah rencana pengembangan model. 


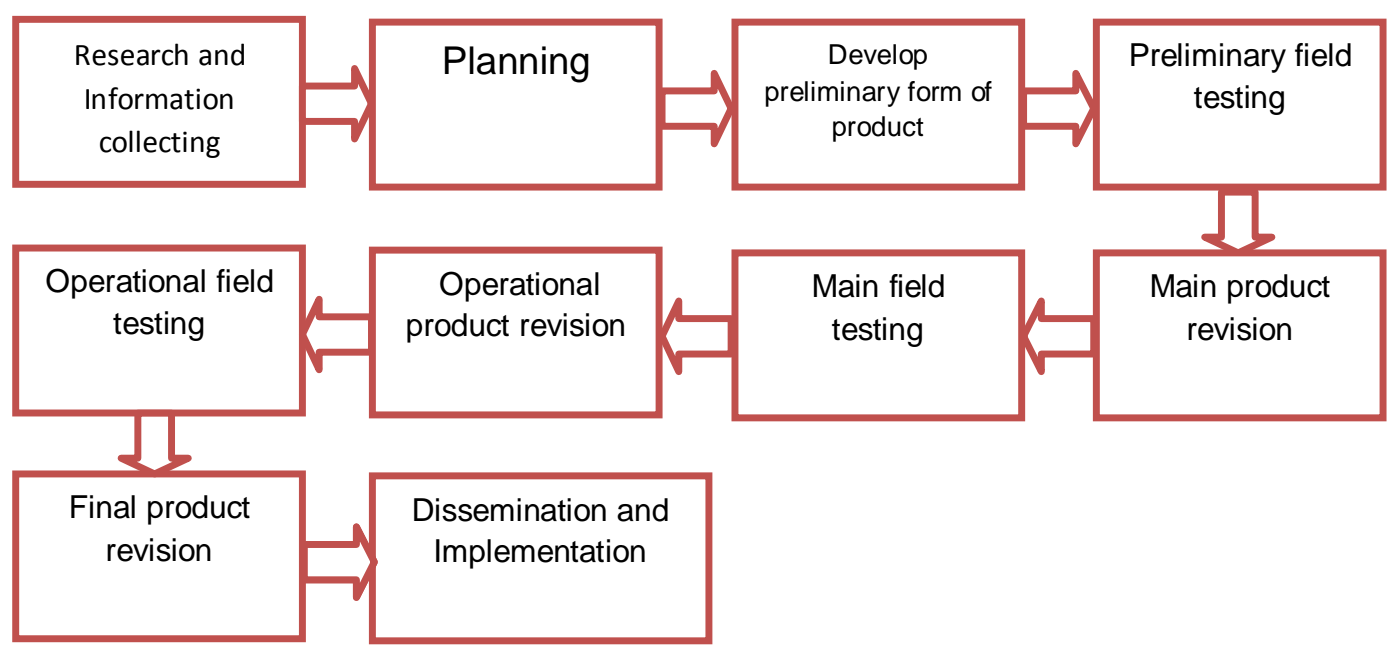

Gambar 1. Langkah-Langkah Penggunaan Metode Research and Development (R\&D) menurut Borg, Walter R \& Gall (1983)

Dalam langkah-langkah pengembangan yang disusun oleh Borg dan Gall sudah sangat jelas, berurutan dan lengkap sehingga peneliti merasa model ini cocok untuk digunakan. Setiap langkahnya telah diurutkan, memiliki tujuan yang jelas dan dilengkapi dengan penjelasan disetiap langkah sehingga proses penelitian yang dilakukan sudah sesuai dengan prosedur penelitian yang ada.

Selain itu penelitian dan pengembangan ini (Borg, Walter R \& Gall, 1983) sangat erat dengan dunia kepelatihan karena banyak penelitian ilmiah merujuk pada desain ini tetapi desain ini juga tepat digunakan dalam pengembangan proses pembelajaran yang dilakukan didalam kelas. Dengan memahami tahapan dalam proses yang terjadi dilapangan, diharapkan akan mampu mengidentifikasi sebuah masalah dengan tepat dengan kebutuhannya dilapangan dalam proses pelatihan sehingga produk yang dikembangkan tepat sasaran. Desain penelitian pengembangan bukan didasarkan pada trial and error. Hal itu akan membutuhkan waktu yang cukup lama.

Dalam penelitian pengembangan ini ada 10 langkah yang mesti lakukan untuk mengetahui seberapa besar efek yang akan dihasilkan dari hasil pengembangan model yang dilakukan, namun dalam penelitian pengembangan yang dilakukan tidak sampai 10 langkah yang lakukan SPORTIF, 5 (1) 2019 | 1-15 
sehingga dalam penelitiaan ini hanya mengetahui sampai mana produk ini dapat diterima oleh pengguna. Cara yang dilakukan dalam mengetahui sampai mana pengguna model ini merasa mudah dan nyaman dalam menggunakan model ini adalah dengan angket yang dibagikan setelah pengguna/atlet mempraktikkan model yang telah dibuat sehingga peneliti dapat mengetahui dan dapat memperbaiki produk yang dirasa kurang baik ketika digunakan dalam proses latihan. Subyek penelitian yang digunakan dalam penelitian ini adalah 40 atlet bola basket Kabupaten Kuningan.

\section{HASIL DAN PEMBAHASAN}

\section{Analisis Kebutuhan}

Pengembangan model latihan konsentrasi pada tembakan free throw ini dilakukan di STKIP Muhammadiyah Kuningan, Program Studi Pendidikan Jasmani Kesehatan dan Rekreasi (PJKR) dengan subjek mahasiswa Prodi PJKR yang telah menempuh mata kuliah Bola Basket. Sesuai dengan langkah pengembangan yang telah dirancang oleh peneliti berdasarkan referensi yang telah dijelaskan, langkah pertama yang dilakukan peneliti adalah melakukan analisis kebutuhan.

Analisis kebutuhan ini dilakukan dengan menyebarkan angket analisis kebutuhan dengan pertanyaan-pertanyaan yang bertujuan untuk mengetahui dibutuhkan atau tidaknya pengembangan sumber belajar ini. Analisis kebutuhan dilaksanakan dengan subjek sebanyak 30 mahasiswa Prodi PJKR yang telah menempuh mata kuliah Bola Basket. Berikut ini adalah data hasil analisis kebutuhan yang diperoleh: 


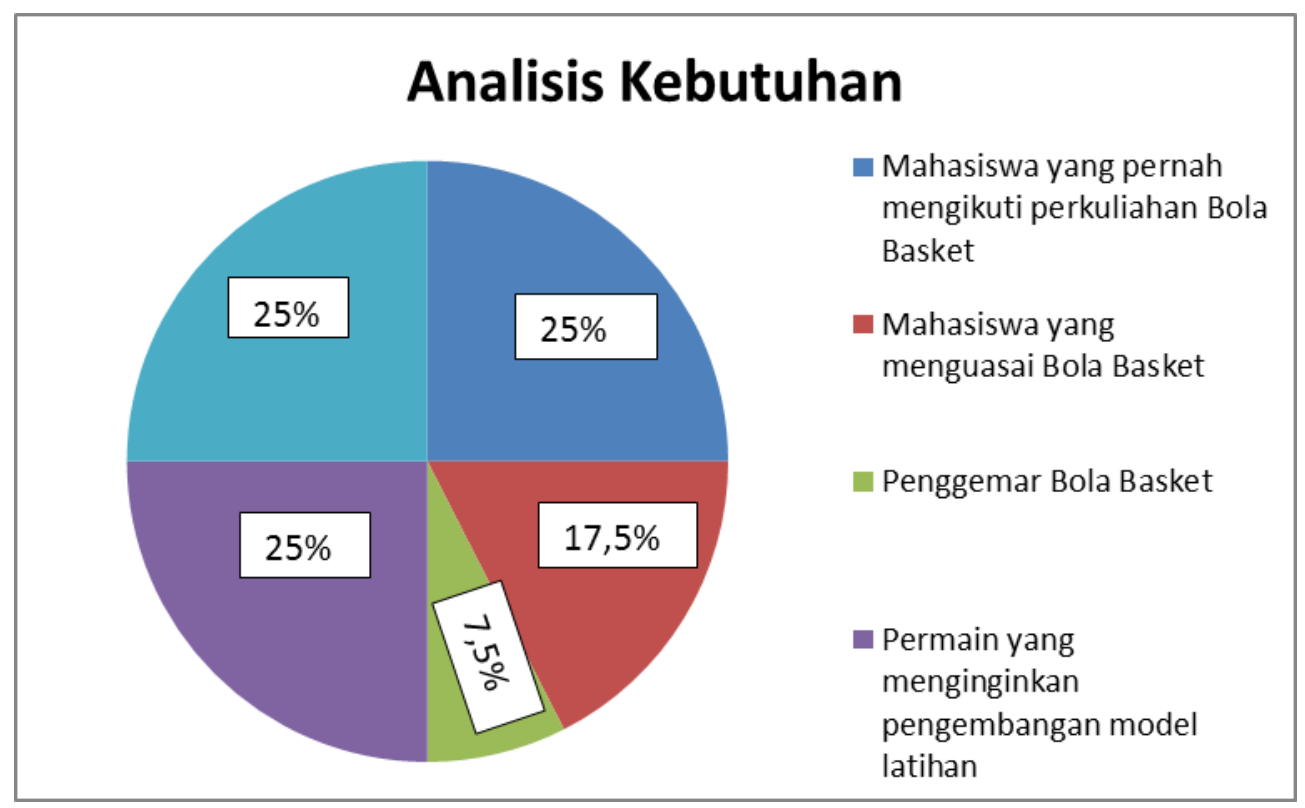

Gambar 2. Analisis Kebutuhan

Dari hasil analisis kebutuhan pada gambar 2, ada beberapa poin penting yang menjadikan kunci perlunya pengembangan dilakukan, diantaranya adalah: 1) 30 mahasiswa atau 100\% mahasiswa pernah mengikuti matakuliah bola basket, 2) 20 mahasiswa atau $70 \%$ mahasiswa masih belum menguasai materi bola basket, 3) 10 mahasiswa $30 \%$ mahasiswa anda menggemari permainan bola basket, 4) 30 mahasiswa $100 \%$ setuju jika diadakan pengembangan model latihan bola basket, 5) 30 mahasiswa 100\% menyatakan bahwa bersedia menggunakan pengembangan model latihan bola basket.

\section{Model Latihan Konsentrasi Pada Tembakan Free Throw}

Tabel 1. Model Latihan Konsentrasi pada Tembakan Free Throw

No




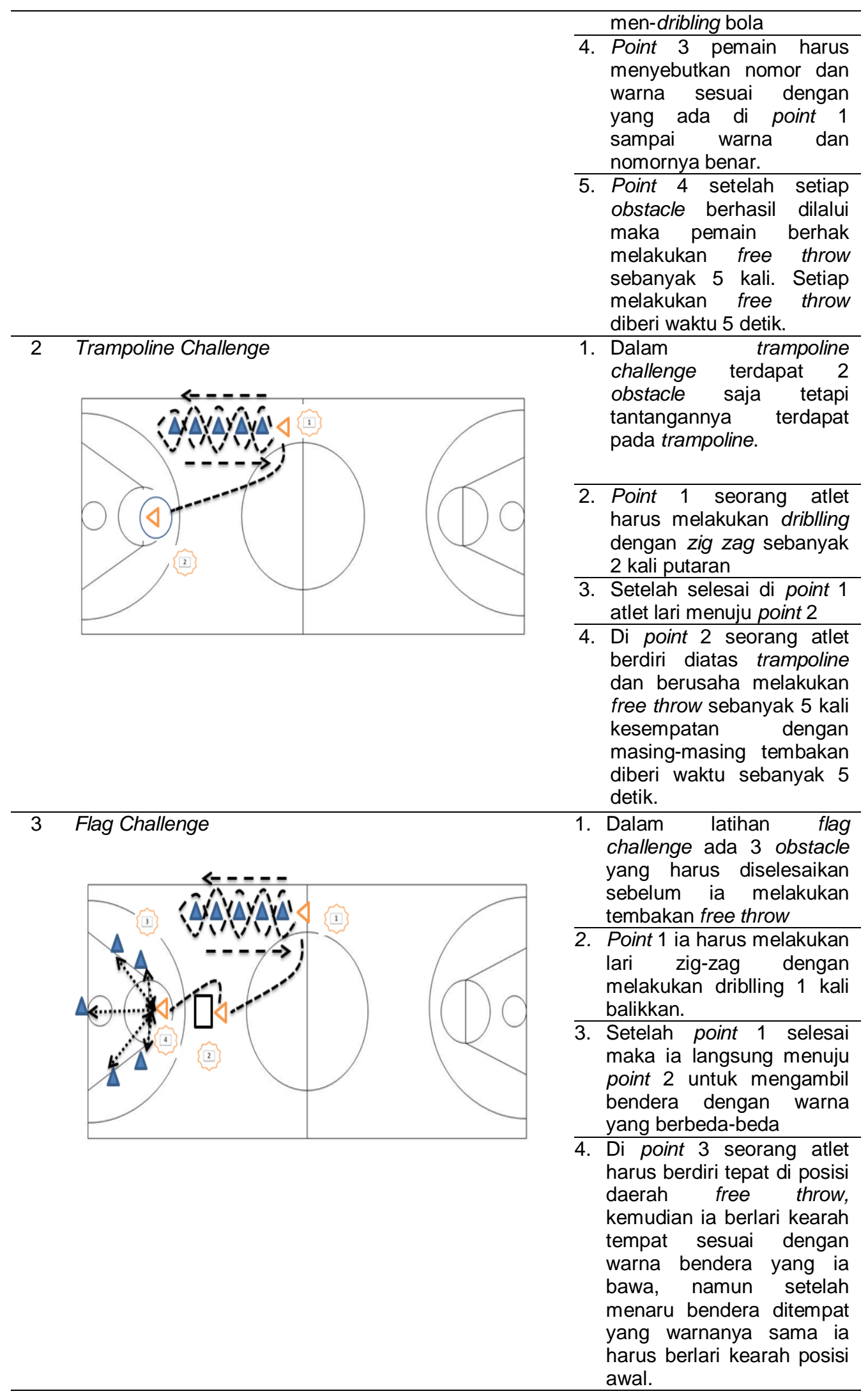




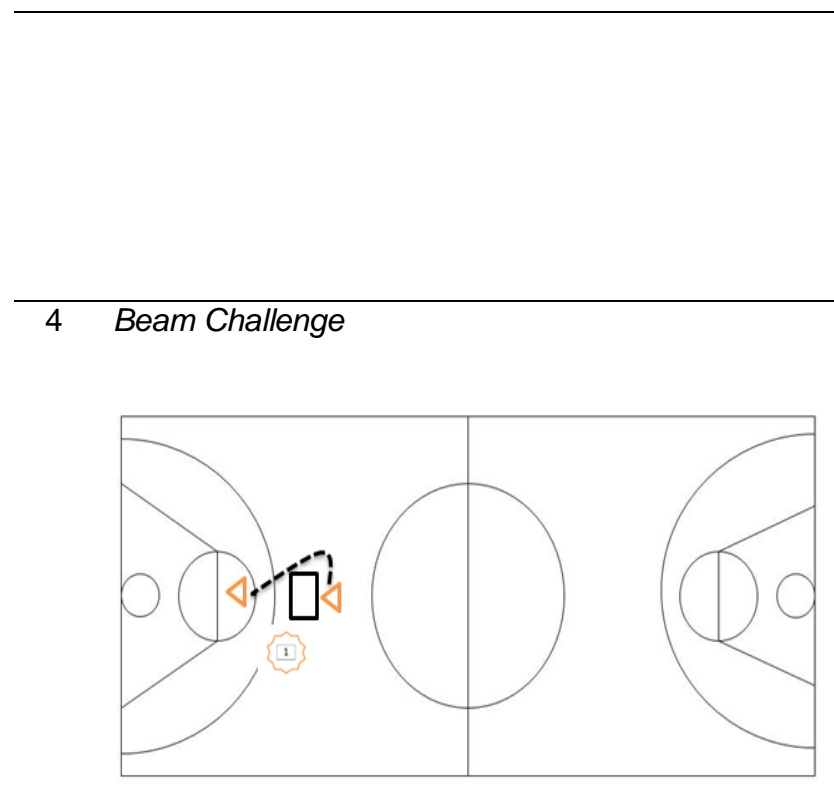

5. Point 4 setelah setiap obstacle brhasil dilalui maka pemain berhak melakukan free throw sebanyak 5 kali. Setiap melakukan free throw diberi waktu 5 detik.

1. Dalam latihan beam challenge ini sangat mudah namun sangat memerlukan konsentrasi yang sangat tinggi guna keberhasilannya

2. Pemain bersiap di tempat tembakan free throw kemudian melakukan tembakan dengan waktu 5 detik setelah itu menuju meja untuk menyusun balok yang disediakan.

3. Balok yang digunakan permainan UNO STAKO 54 balok. Setiap pemain yang akan melakukan tembakan free throw harus mengambil 4 balok tanpa merubuhkan bangunan balok.

a. Dalam latihan jump \& passing ini sangat sederhana pemain hanya akan melewati 2 obstacle saja dengan beberapa Variasi dalam

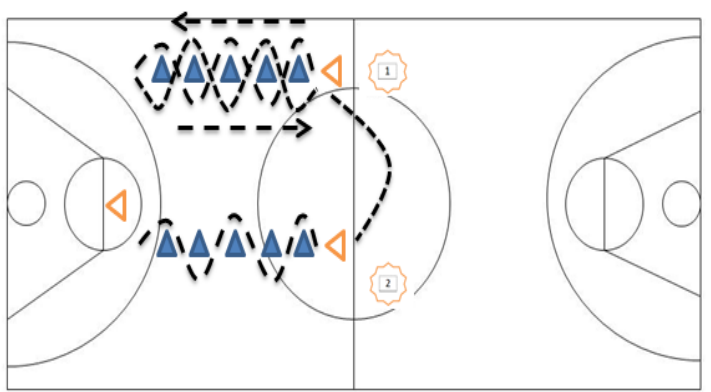
pelaksanaannya.

b. Point 1 pemain harus melakukan lari zig-zag sambil melakukan driblling bola sebanyak 2 putara.

c. Setelah selesai di point 1 pemain berlari ke point 2 untuk melaukan lompatan setinggi $20 \mathrm{~cm}$.

d. Lompatan yang dilakukan menggunakan dua kaki bukan satu kaki, setelah melompat disetiap cone, maka pemain menerima passing bola dan harus mengembalikkannya lagi. Passing yang sukses maka berhak melanjutkan hingga ke posisi tembakan free throw.

e. Setelah setiap obstacle berhasil dilalui maka pemain berhak melakukan free throw sebanyak 5 kali. Setiap melakukan free throw diberi waktu 5 detik. 


6 Fazel Challenge $\begin{aligned} & \text { a. } \begin{array}{l}\text { Dalam latihan fazel } \\ \text { challenge ini sangat } \\ \text { mudah namun sangat } \\ \text { memerlurkan konsentrasi } \\ \text { yang sangat tinggi guna } \\ \text { keberhasilannya }\end{array} \\ & \begin{array}{l}\text { boint 1 pemain harus } \\ \text { menyusun fazel yang telah } \\ \text { disediakan 1 demi 1 } \\ \text { dengan jumlah fazel ada 5 } \\ \text { fazel yang berbeda. }\end{array} \\ & \begin{array}{l}\text { Setiap fazel yang telah } \\ \text { selesai disusun maka } \\ \text { pemain langsung menuju } \\ \text { ke point 2. }\end{array} \\ & \begin{array}{l}\text { Point 2 pemain harus } \\ \text { melakukan tembakan free } \\ \text { throw dimana setiap } \\ \text { tembakan diberikan waktu } \\ \text { pelaksanaan selama 5 } \\ \text { detik. }\end{array}\end{aligned}$

\section{Analisis Data Uji Coba Kelompok Kecil, Sedang dan Besar}

Setelah produk model latihan konsentrasi tembakan free throw pada bola basket di uji cobakan pada uji coba kelompok kecil, sedang dan besar maka setelah melakukan uji coba produk akan mengalami perubahan oleh para ahli agar sesuai dengan kondisi sebenarnya dan efektif saat digunakan ketika proses latihan. Saat produk itu diuji cobakan kepada sampel dan juga meminta saran pada pakar maka produk di uji cobakan dengan melibatkan atlet.

Hasil uji coba kelompok kecil, kelompok sedang dan kelompok besar pada pengembangan latihan konsentrasi tembakan free throw pada bola basket sebagai berikut:

Tabel 2. Analisis Data Uji Coba Kelompok Kecil, Sedang dan Besar

\begin{tabular}{cc}
\hline Kategori Uji Coba & Skor (\%) \\
\hline Uji Coba Kelompok Kecil & 82,10 \\
\hline Uji Coba Kelompok Sedang & 87,56 \\
\hline Uji Coba Kelompok Besar & 90,49 \\
\hline
\end{tabular}

(Sumber: pengolahan data)

Dalam proses pengumpulan data yang dilakukan dapat diartikan bahwa perubahan skor yang didapat dalam setiap uji coba sangat menentukan apakah proses pengembangan yang dilakukan dapat diterima oleh setiap sampel yang mencoba proses latihan tersebut. Dengan kata lain bahwa pengembangan latihan kosentrasi tembakan free 
throw pada bola basket sangat layak digunakan dalam setiap proses latihan yang dilakukan, hal ini pun akan menjadi sebuah kekhasan dalam proses latihan yang dilakukan.

Dari rangkaian proses yang telah dilakukan dimulai dari analisis kebutuhan, pembuatan model latihan, uji coba kelompok kecil sampai pada uji coba kelompok besar. Rangkaian proses pengembangan telah seluruhnya dilakukan meski tidak sampai pada taraf efektivitas produk namun pengembangan yang dilakukan hanya sampai pada pembuatan produk. Hal ini pun telah menunjukkan bahwa produk yang dibuat memang sangat dibutuhkan bagi para pelatih dan para pemain guna menambah sebuah wawasan baru dan khazanah baru dalam ilmu kepelatihannya terlebih mengenai tuntutan zaman yang semakin hari menuntut seorang pelatih mampu memaksimalkan potensi yang dimiliki seorang atletnya.

Dalam perkembangan ilmu olahraga latihan mental menjadi sebuah menu latihan yang diterapkan oleh seorang pelatih namun terkadang pelatih sangat bingung bagaimana latihan mental ini dapat digabungkan dengan latihan-latihan yang lain. Pengembangan ini sedikit membuka wawasan bagi pelatih dan atlet cara menggabungkan latihan mental lebih khususnya latihan konsentrasi dapat dipadupadankan dengan jenis latihan yang lain dan tidak terpisah degan menu latihan yang lainnya, sehingga model latihan ini sangat perlu dikembangkan untuk dapat menambah pengetahuan dan pengalaman melatih atletnya.

\section{KESIMPULAN DAN SARAN}

\section{Kesimpulan}

Penelitian dan pengembangan ini menghasilkan sebuah produk model latihan konsentrasi pada tembakan free throw. Dengan adanya pengembangan model latihan konsentrasi pada tembakan free throw ini kepada mahasiswa, pelatih dan dosen pengampu mata kuliah bola basket dapat mempelajari dan melaksanakan model latihan passing bola basket secara efektif dan efisien, sehingga mahasiswa dapat menguasai materi teori dan praktik bola basket dengan cepat dan benar. 


\section{Saran}

Pengembangan model latihan konsentrasi pada tembakan free throw ini bisa digunakan sebagai tambahan referensi bagi dosen pengampu matakuliah bola basket, pelatih bola basket dan mahasiswa Program Studi Pendidikan Jasmani Kesehatan dan Rekreasi yang sedang menempuh matakuliah bola basket atau dalam menunjang program latihan yang sedang dilakukan. Pengembangan model latihan konsentrasi bola basket memuat berbagai macam model latihan free throw dan panduan pelaksanaannya dengan singkat dan mudah dipahami sehingga sangat disarankan bagi pelatih dan mahasiswa untuk dimanfaatkan dalam mendalami materi bola basket.

Dalam mengembangkan penelitian ini ke arah lebih lanjut, peneliti mempunyai beberapa saran kepada para peneliti yang akan mengembakan model latihan ini, sebagai berikut:

a. Model latihan ini berpotensi untuk dapat dikelola dan dikembangkan lebih lanjut dalam bentuk atau kemasan yang lebih mudah sehingga memudahkan ketika dalam proses latihan ataupun pembelajaran.

b. Peneliti mencoba menambahkan video peragaan kepada produk yang dikembangkan sehingga dapat mempermudah dalam bentuk pelaksanaannya dilapangan.

\section{DAFTAR PUSTAKA}

Alexander, M. J. L. (2016). The Effectiveness of the Shotloc Training Tool on Basketball Free Throw Performance and Technique. International Journal of Kinesiology \& Sports Science, 4(2), 43-54. https://doi.org/10.7575/aiac.ijkss.v.4n.2p.43

Borg, Walter R \& Gall, M. D. (1983). Educational Research (An introduce). White Plains, NY, England: Longman Publishing.

Diane, L. (2009). Free-Throw Shooting During Dual-Task Performance: Implications for Attentional Demand and Performanc. Research Quarterly for Exercise and Sport, 80(4), 718.

Kurniawan, Noris Alim \& Sudarso, S. (2014). Hubungan antara Tingkat 
Konsentrasi Siswa dengan Ketepatan Free Throw dalam Permainan Bola Basket. Jurnal Pendidikan Olahraga dan Kesehatan, 2(1), 249-252.

Ramadan, G., \& Iskandar, D. (2018). Pengaruh Gaya Mengajar dan Motivasi Belajar Terhadap Hasil Belajar Lay Up Shoot. JPE (Jurnal Pendidikan Edutama), 5(1), 91-100.

Raôui, R. D., \& Thomas, W. J. (2012). Training Visual Control in Wheelchair Basketball Shooting. Research Quarterly for Exercise and Sport, 83(3), 464-469.

Robert, N. (2010). Teaching preperformance routines to beginners. Journal of physical education, recreation and dance, 71(7), 34.

Rosmi, Y. F. (2017). Pengaruh Latihan Autogenic Relaxation Terhadap Konsentrasi dan Keberhasilan Fre Throw Bola Basket. Helper, 34(2), 81-98.

Sarang, R. (2018). A New Learning Control System for Basketball Free Throws Based on Real Time Video Image Processing and Biofeedback. Engineering, Technology \& Applied Science Research, 8(1), 2405-2411.

Setiawan, A. I., Kurniawati, Y., Fitriani, A., Psikologi, P. S., Brawijaya, U., \& Basket, P. B. (2015). Internal Focus Of Control dan Self-Efficacy Pemain Bola Basket dalam Melakukan Free Throw. Jurnal Mediapsi, 1(1), 17-27.

Wang, J., Wang, Y., \& Ma, J. (2013). Training of Basketball Referees in Basketball. Journal of Theoretical and Information Technology, 48(2), 850-857. 